Editor's Note: These short reviews of recent JNeurosci articles, written exclusively by students or postdoctoral fellows, summarize the important findings of the paper and provide additional insight and commentary. If the authors of the highlighted article have written a response to the Journal Club, the response can be found by viewing the Journal Club at www.jneurosci.org. For more information on the format, review process, and purpose of Journal Club articles, please see http://jneurosci.org/content/ preparing-manuscript\#journalclub.

\title{
Insights into the Neurobiology of Anxiety and a Potential Target for Pharmacotherapy
}

\author{
- Rami Hamati ${ }^{1,2}$ \\ ${ }^{1}$ Department of Cellular and Molecular Medicine, Faculty of Medicine, University of Ottawa, Ottawa, Ontario K1H 8L1, Canada, and 2Mood Disorders \\ Research Unit, Royal Institute of Mental Health Research, Ottawa, K1Z 7K4, Ontario, Canada \\ Review of Ahrens et al.
}

Exposure to a stressful event activates noradrenergic neurons of the locus ceruleus, and noradrenaline is released near cells of the limbic system, including the hippocampus and amygdala, which express $\alpha$-and $\beta$-adrenergic receptors (Krugers et al., 2012; Szabadi, 2013). After a delay, corticotropin-releasing hormone $(\mathrm{CRH})$ is released from neurons in the hypothalamic median eminence and acts on $\mathrm{CRH}$ receptors in the pituitary leading to corticosteroid release in the periphery (Joëls and Baram, 2009; Krugers et al., 2012). $\mathrm{CRH}$ receptors were previously thought to be only important in regulating endocrine responses (Bruchas et al., 2010). Now, several studies have demonstrated that $\mathrm{CRH}$ receptors are widely distributed in the brain, including the extended amygdala complex, suggesting that $\mathrm{CRH}$ interacts with several other neurotransmitters to mediate the stress response centrally (Joëls and Baram, 2009). The extended amygdala complex contains key regions, including the CeA and the BNST. Previous studies have suggested that the

Received June 8, 2018; revised Aug. 27, 2018; accepted Sept. 2, 2018.

I thank Dr. Pierre Blier and Dr. Jennifer Phillips for comments on the paper.

The author declares no competing financial interests.

Correspondence should be addressed to Rami Hamati, University of Ot-

tawa, 451 Smyth Road, Ottawa, Ontario K1H 8L1, Canada. E-mail: rhama036@uottawa.ca.

DOI:10.1523/JNEUROSCI.1461-18.2018

Copyright $\odot 2018$ the authors $\quad 0270-6474 / 18 / 388919-03 \$ 15.00 / 0$
CeA and the BNST have distinct roles, mediating phasic and sustained (anxietylike) fear, respectively (Davis et al., 2010). However, other studies have suggested that these brain regions orchestrate fear and anxiety states together. For example, a recent fMRI study found that activity in both the amygdala and the BNST is altered in people with generalized anxiety disorder (Yassa et al., 2012). Coordinated responses in CeA and BNST would not be surprising given that the CeA sends strong inhibitory projections to the BNST (Dong et al., 2001; Oler et al., 2017).

Ahrens et al. (2018) recently investigated the relationship between the lateral division of the CeA (CeL) and the BNST at the molecular level. Because somatostatinexpressing $\left(\mathrm{SOM}^{+}\right)$cells in the $\mathrm{CeL}$ are essential for the acquisition and recall of fearful memories, as well as defensive behaviors (Yu et al., 2016), Ahrens et al. (2018) explored whether SOM ${ }^{+}$CeL neurons alter activity in the BNST, and whether changing the relationship between these brain regions produces anxiety-related behaviors. Previous experiments demonstrated that global deletion of the tyrosine kinase ErbB4 from $\mathrm{SOM}^{+}$cells in mice produced an anxietylike phenotype as assessed by the open field test and the elevated plus maze test (Ahrens et al., 2015). In the open field test, ErbB4-deficient mice showed reduced time spent in the open arms and a reduced number of entries into the open arms (Ahrens et al., 2018, their Fig. 1A). In the elevated plus maze test, ErbB4-deficient mice displayed reduced time spent in the center and a reduced number of entries into the center (Ahrens et al., 2018, their Fig. $1 B$ ). Deleting ErbB4 selectively in $\mathrm{SOM}^{+} \mathrm{CeL}$ neurons also produced an anxiety-like phenotype. Additionally, ErbB4 deletion potentiated excitatory synaptic transmission onto $\mathrm{SOM}^{+}$CeL neurons by increasing the frequency of miniature EPSCs (mEPSCs) (Ahrens et al., 2018, their Fig. $3 B, C$ ). To determine whether increasing excitatory input to $\mathrm{SOM}^{+} \mathrm{CeL}$ neuron was responsible for the increase in anxiety-like phenotype in ErbB4 mutants, Ahrens et al. (2018) expressed a mutant form of the glutamate ionotropic receptor AMPA subunit 2 (GLUA2) selectively in these neurons in otherwise wild-type mice. This replicated the anxiety-like phenotype, indicating that hyperactive $\mathrm{SOM}^{+}$CeL neurons are sufficient to produce anxiety-like behaviors.

The CeL is functionally connected to the BNST (Dong et al., 2001; Oler et al., 2017), and retrograde tracing performed by Ahrens et al. (2018) confirmed that $\mathrm{SOM}^{+} \mathrm{CeL}$ neurons innervate $\mathrm{SOM}^{+}$ and $\mathrm{SOM}^{-}$neurons in the dorsal BNST (dBNST) (Ahrens et al., 2018, their Fig. $5 A-E)$. Despite the increased excitatory drive to $\mathrm{SOM}^{+} \mathrm{CeL}$ neurons with inhibitory projections to the $\mathrm{dBNST}$, the fre- 
quency of spontaneous IPSCs (sIPSCs) onto $\mathrm{SOM}^{+} \mathrm{dBNST}$ neurons was reduced in ErbB4-mutant mice. Because $\mathrm{SOM}^{+}$ neurons in the amygdala typically release the inhibitory neurotransmitter GABA (McDonald and Mascagni, 2002; Saha et al., 2002), it is paradoxical that increasing excitatory drive to $\mathrm{SOM}^{+} \mathrm{CeL}$ neurons leads to disinhibition of $\mathrm{SOM}^{+}$dBNST neurons. There are two possible explanations for this finding. First, $\mathrm{SOM}^{+} \mathrm{CeL}$ neurons might reduce GABAergic transmission onto $\mathrm{SOM}^{+}$dBNST indirectly, via other unknown neuronal populations. But this was previously ruled out (Li et al., 2012). Alternatively, as Ahrens et al. (2018) suggest, $\mathrm{SOM}^{+}$CeL neurons corelease a neuromodulator that regulates inhibitory neurotransmission. In support of the latter hypothesis, RNA sequencing of $\mathrm{SOM}^{+} \mathrm{CeL}$ neurons revealed that they express high levels of prodynorphin RNA, a gene encoding a precursor of the endogenous $\kappa$-receptor agonist dynorphin. To determine whether enhanced dynorphin release mediated the reduction of inhibitory neurotransmission onto $\mathrm{SOM}^{+}$ BNST neurons, Ahrens et al. (2018) treated dBNST slices with norbinaltorphimine (norBNI), a selective $\kappa$-opioid receptor antagonist; this treatment restored inhibitory synaptic transmission onto $\mathrm{SOM}^{+}$dBNST neurons in ErbB4 mutants, but not in wild-type mice. These data suggest that hyperactive $\mathrm{SOM}^{+} \mathrm{CeL}$ neurons disinhibit $\mathrm{SOM}^{+}$dBNST neurons by increasing dynorphin signaling at the synapse.

Notably, the authors recapitulated their findings in the acute stress model. If an acute stressor affects CeL and dBNST neurons, such as ErbB4 deletion, then these data may provide insight about the neurobiology of anxiety. Administering uncontrolled and unpredictable foot shocks increased anxiety-like behaviors in wildtype mice compared with mice that did not receive foot shocks. Subsequent electrophysiological recordings revealed an increase in mEPSCs onto $\mathrm{SOM}^{+} \mathrm{CeL}$ neurons and a reduction of sIPSCs onto $\mathrm{SOM}^{+}$dBNST neurons. Furthermore, inhibitory synaptic transmission onto dBNST neurons was restored after exposure of acute dBNST slices to norBNI. Importantly, norBNI infusion into the dBNST of behaving ErbB4 mutant mice reduced anxiety-like behaviors. The behavioral effects of norBNI infusion into the dBNST of acutely stressed wild-type mice was not reported, however. Therefore, selective $\kappa$-opioid receptor antagonism may not be anxiolytic in intact mice limiting the translational potential of the results.

Dynorphin is intimately connected to the stress response. Following acute stress or intracerebroventricular injection of $\mathrm{CRH}$, phosphorylation of $\kappa$-opioid receptors, an indicator of agonist binding to the $\kappa$-opioid receptor, increased in several brain regions, including the extended amygdala (Land et al., 2008). Furthermore, intra-amygdala injection of $\mathrm{CRH}$ increased extracellular dynorphin concentration in the CeA as measured by microdialysis in rats (Lam and Gianoulakis, 2011). Therefore, it is not surprising that activation of the hypothalamo-pituitaryadrenal axis via acute uncontrolled footshocks increased dynorphin release onto $\mathrm{SOM}^{+}$dBNST neurons (Ahrens et al., 2018, their Fig. 9C,E). A surge in CRH after an acute stressor may lead to the activation of $\mathrm{CRH}$ receptors on putative $\mathrm{SOM}^{+}$CeL neurons (Asok et al., 2018), subsequent dynorphin release and $\kappa$-opioid receptor activation. The $\kappa$-opioid receptor is coupled to a G-inhibitory protein, and activation of the receptor may hyperpolarize neurons via increasing potassium conductance and/or decreasing calcium conductance (Bruchas et al., 2010). However, in the present study, Ahrens et al. (2018) reported that $\kappa$-opioid receptor antagonism restored sIPSCs onto dBNST neurons $24 \mathrm{~h}$ after foot-shocks, suggesting that the expression and activation of $\kappa$-opioid receptors on postsynaptic dBNST neurons are unlikely. Indeed, previous research has demonstrated that the ability of $\kappa$-opioid receptors to inhibit GABA release is dependent on ERK signaling activated presynaptically in CeA neurons ( $\mathrm{Li}$ et al., 2012). Together, the above evidence suggests that $\mathrm{SOM}^{+} \mathrm{CeL}$ neurons regulate GABAergic tone onto the dBNST through the activation of presynaptic $\kappa$-opioid receptors. To relate these findings more closely to anxiety states in humans, future studies should assess the consequences of chronically elevated dynorphin signaling at the CeLdBNST synapse. An intense or repeated stressor may increase dynorphin signaling to the point of desensitizing and/or internalizing $\kappa$-opioid receptors. $\kappa$-Opioid receptor desensitization has previously been shown to depend on G-protein receptor kinase phosphorylation of the agonistbound form, elicited by dynorphin binding (Al-Hasani and Bruchas, 2011). Indeed, prolonged $\kappa$-opioid receptor activation by the $\kappa$-opioid receptor agonist $\mathrm{U} 50,488$ resulted in increased receptor phosphorylation and analgesic tolerance in vivo (McLaughlin et al., 2004). Thus, $\kappa$-opioid receptor desensitization could disrupt CeL-dBNST functional homeostasis and contribute to the manifestation of chronic anxiety-like states.

The experiments by Ahrens et al. (2018) have provided evidence for a novel therapeutic target in the treatment of anxiety disorders. Indeed, dysregulated $\kappa$-opioid signaling has been implicated in psychiatric disorders, such as addiction and depression (Bruchas et al., 2010). Moreover, administration of buprenorphine (a partial $\mu$-opioid receptor agonist and $\kappa$-receptor antagonist) together with samidorphan (a $\mu$-opioid receptor antagonist) significantly decreased depressive symptoms in patients with treatmentresistant major depressive disorder (Fava et al., 2016). Furthermore, Almatroudi et al. (2018) showed that BU10119, a shortacting $\mu$-/ $\kappa$-opioid receptor antagonist, relieved anxiety-like symptoms in mice. Whereas BU10119 significantly decreased the latency to drink in a novelty-induced hypophagia task, it had no effect on two other tasks that are thought to measure anxiety-like symptoms: the elevated plus maze task and the light-dark exploration test (Dulawa and Hen, 2005; Griebel and Holmes, 2013), possibly because these tests were not sufficiently stressful (Almatroudi et al., 2018). Nonetheless, the study by Ahrens et al. (2018) provides evidence that increased dynorphin release caused by dysregulation of the extended amygdala may be involved in the pathophysiology of anxiety disorders. Future studies should explore the efficacy of $\kappa$-opioid receptor antagonists in relieving anxiety, using intense acute or chronic stress models and anxiety-sensitive assays in wild-type rodents. If successful, blockade of $\kappa$-opioid receptors could be developed as a potential pharmacotherapy in the treatment of anxiety disorders in humans.

\section{References}

Ahrens S, Jaramillo S, Yu K, Ghosh S, Hwang GR, Paik R, Lai C, He M, Huang ZJ, Li B (2015) ErbB4 regulation of a thalamic reticular nucleus circuit for sensory selection. Nat Neurosci 18:104-111. CrossRef Medline

Ahrens S, Wu MV, Furlan A, Hwang GR, Paik R, Li H, Penzo MA, Tollkuhn J, Li B (2018) A central extended amygdala circuit that modulates anxiety. J Neurosci 38:55675583. CrossRef Medline

Al-Hasani R, Bruchas MR (2011) Molecular mechanisms of opioid receptor-dependent signaling and behavior. Anesthesiology 115: 1363-1381. CrossRef Medline

Almatroudi A, Ostovar M, Bailey CP, Husbands SM, Bailey SJ (2018) Antidepressant-like effects of BU10119, a novel buprenorphine an- 
alogue with mixed $\kappa / \mu$ receptor antagonist properties, in mice. Br J Pharmacol 175:28692880. CrossRef Medline

Asok A, Draper A, Hoffman AF, Schulkin J, Lupica CR, Rosen JB (2018) Optogenetic silencing of a corticotropin-releasing factor pathway from the central amygdala to the bed nucleus of the stria terminalis disrupts sustained fear. Mol Psychiatry 23:914-922. CrossRef Medline

Bruchas MR, Land BB, Chavkin C (2010) The dynorphin/kappa opioid system as a modulator of stress-induced and pro-addictive behaviors. Brain Res 1314:44-55. CrossRef Medline

Davis M, Walker DL, Miles L, Grillon C (2010) Phasic vs sustained fear in rats and humans: role of the extended amygdala in fear vs anxiety. Neuropsychopharmacology 35:105-135. CrossRef Medline

Dong H, Petrovich GD, Swanson LW (2001) Topography of projections from amygdala to bed nuclei of the stria. Brain Res 38:192-246. CrossRef Medline

Dulawa SC, Hen R (2005) Recent advances in animal models of chronic antidepressant effects: the novelty-induced hypophagia test. Neurosci Biobehav Rev 29:771-783. CrossRef Medline

Fava M, Memisoglu A, Thase ME, Bodkin JA, Trivedi MH, de Somer M, Du Y, LeighPemberton R, DiPetrillo L, Silverman B, Ehrich E (2016) Opioid modulation with Buprenorphine/Samidorphan as adjunctive treatment for inadequate response to antide- pressants: a randomized double-blind. Am J Psychiatry 173:499-508. CrossRef Medline

Griebel G, Holmes A (2013) 50 years of hurdles and hope in anxiolytic drug discovery. Nat Publ Gr 12:667-687. CrossRef Medline

Joëls M, Baram TZ (2009) The neuro-symphony of stress. Nature 10:459-466. CrossRef Medline

Krugers HJ, Karst H, Joëls M (2012) Interactions between noradrenaline and corticosteroids in the brain: from electrical activity to cognitive performance. Front Cell Neurosci 6:15. CrossRef Medline

Lam MP, Gianoulakis C (2011) Effects of acute ethanol on corticotropin-releasing hormone and $\beta$-endorphin systems at the level of the rat central amygdala. Psychopharmacology (Berl) 218:229-239. CrossRef Medline

Land BB, Bruchas MR, Lemos JC, Xu M, Melief EJ, Chavkin C (2008) The dysphoric component of stress is encoded by activation of the dynorphin $\kappa$-opioid system. J Neurosci 28: 407-414. CrossRef Medline

Li C, Pleil KE, Stamatakis AM, Busan S, Vong L, Lowell BB, Stuber GD, Kash TL (2012) Presynaptic inhibition of gamma-aminobutyric acid release in the bed nucleus of the stria terminalis by kappa opioid receptor signaling. Biol Psychiatry 71:725-732. CrossRef Medline

McDonald AJ, Mascagni F (2002) Immunohistochemical characterization of somatostatin containing interneurons in the rat basolateral amygdala. Brain Res 943:237-244. CrossRef Medline

McLaughlin JP, Myers LC, Zarek PE, Caron MG,
Lefkowitz RJ, Czyzyk TA, Pintar JE, Chavkin C (2004) Prolonged kappa opioid receptor phosphorylation mediated by G-protein receptor kinase underlies sustained analgesic tolerance. J Biol Chem 279:1810-1818. CrossRef Medline

Oler JA, Tromp DP, Fox AS, Kovner R, Davidson RJ, Alexander AL, McFarlin DR, Birn RM, Berg EB, deCampo DM, Kalin NH, Fudge JL (2017) Connectivity between the central nucleus of the amygdala and the bed nucleus of the stria terminalis in the non-human primate: neuronal tract tracing and developmental neuroimaging studies. Brain Struct Funct 222:21-39. CrossRef Medline

Saha S, Henderson Z, Batten TF (2002) Somatostatin immunoreactivity in axon terminals in rat nucleus tractus solitarii arising from central nucleus of amygdala: coexistence with GABA and postsynaptic expression of sst 2A receptor. J Chem Neuroanat 24:1-13. CrossRef Medline

Szabadi E (2013) Functional neuroanatomy of the central noradrenergic system. J Psychopharmacol 27:659-693. CrossRef Medline

Yassa MA, Hazlett RL, Stark CE, Hoehn-Saric R (2012) Functional MRI of the amygdala and bed nucleus of the stria terminalis during conditions of uncertainty in generalized anxiety disorder. J Psychiatr Res 46:10451052. CrossRef Medline

Yu K, Garcia da Silva P, Albeanu DF, Li B (2016) Central amygdala somatostatin neurons gate passive and active defensive behaviors. J Neurosci 36:6488-6496. CrossRef Medline 